\title{
Consolidating the Putin Regime: The 2020 Referendum on Russia's Constitutional Amendments
}

\author{
Derek S. Hutcheson | ORCID: 0000-0001-5993-0788 \\ Professor, Department of Global Political Studies, Faculty of Culture \\ and Society, Malmö University, Malmö, Sweden \\ derek.hutcheson@mau.se \\ Ian McAllister | ORCID: 0000-0001-8448-6738 \\ Professor, Research School of Social Sciences, College of Arts \& Social \\ Sciences, Australian National University, Canberra, ACT, Australia \\ ian.mcallister@anu.edu.au
}

\begin{abstract}
In July 2020 , Russian voters gave strong support to a package of constitutional reforms that reconfigured the Russian political system and enshrined social guarantees and conservative identity values, consolidating the regime that has been built over a 20 -year period. This was achieved through an alteration that 'zeroed' presidential terms that commenced before the constitutional change, potentially allowing President Vladimir Putin to overcome term limits and continue in office beyond 2024. The article explains how such a far-reaching and important change was successfully endorsed by the Russian electorate. The analysis shows that the main explanation rests with variations in voting patterns across the regions, a pattern that has been evident in previous Russian elections and resulted in strong pro-Putin support. The article also evaluates questions raised about the legitimacy of the result, and its long-term significance for the Russian political system.
\end{abstract}

\section{Keywords}

Russia - elections - electoral behavior - constitution - referendum - Putin 
In a week-long vote that culminated on 1 July 2020 , Russians went to the polls to confirm the constitutional changes announced by President Vladimir Putin in his January 2020 address to the Federal Assembly. This was the first nationwide vote outside the standard parliamentary and presidential electoral cycle since the December 1993 referendum that had ratified the post-Soviet Russian constitution. Like that earlier referendum, its key significance lay in its implications for the future of the Russian presidency. By effectively resetting the clock on Vladimir Putin's previous time in office to bypass the two consecutive term limit, he is no longer proscribed from standing again in 2024. This reduces the likelihood of him becoming a 'lame duck' outgoing president for the remainder of his present mandate. Should he choose to do so, it potentially allows him to remain in office until 2036, health and public support permitting.

The 'zeroing' of Putin's term count was the most politically significant reform approved in the referendum, but it hardly featured at all in the actual campaign. The issue was buried amongst a myriad of other constitutional changes that codified social guarantees and conservative values into the country's basic law. Approved by 77.92 percent of those who voted, the constitutional amendments made extensive alterations to the Russian constitution - some cosmetic, and others more substantial. How did such a far-reaching constitutional change come to be approved by voters, with relatively little debate? As we argue in this article, the answer rests in two aspects of the election. First, the change in the presidential term limit was one of 206 changes, and voters could only support or oppose them as a package. ${ }^{1}$ Even trenchant opponents of the term limits change could find other parts of the reform package that they agreed with. Second, the regime relied on long-standing patterns of regional voting, encouraging turnout in regions supportive of the regime and discouraging it in others. The outcome was a large majority in support of the changes, on a respectable turnout of 67.97 percent.

The paper proceeds as follows. In the next section we examine the context of the election, focusing on the popularity of the Putin regime, the context

1 B.S. Ebzeev, "Aktualizatsiya Konstitutsii Rossii: sobiratel'nyi obraz popravok Prezidenta RF V.V. Putina i novye smysly Osnovnogo Zakona", Gosudarstvo i pravo, no. 4 (2020): 7-24; Gudrun Persson, Carolina Vendil Pallin and Maria Engqvist, "Ryssland ändrar grundlagen innehåll och konsekvenser", Swedish Defence Research Agency, FOI Memo 7091, 4 May 2020, https://www.foi.se/en/foi/reports/report-summary.html?reportNo=FOI\%2OMemo\%2O7091 (accessed 22 January 2021); Elizabeth Teague, "Russia's Constitutional Reforms of 2020", Russian Politics 5, no. 4 (2020): 301-28. 
of the term limit debate, and the announcements of the proposed changes. The second section covers the referendum campaign and the electoral framework that was put in place for voting, a process made more complicated by the Coronavirus (COVID-19) pandemic. The third section analyses the regional patterns of voting and shows how the regime maximized turnout (and support for the changes) in regions that have been long-standing supporters of the regime, while discouraging turnout in less supportive regions. The fourth section provides an overview of the debates about the fairness of the election and concludes that, while the overall outcome was not in doubt, substantial proportions of voters had considerable reservations about the electoral procedures. Finally, in the conclusion we discuss the long-term implications of the referendum for Russian politics.

\section{2 The Electoral Context}

Most political leaders' support wanes over time, but even after over 20 years in power - a cumulative 16 years as president, four-and-a-half as prime minister Vladimir Putin's popularity remained historically high at the start of the new decade. As Figure 1 shows, two-thirds of voters continued to approve of his actions as president at the beginning of 2020. Even if this was slightly below the 2o-year average of 75 percent, it still represented a substantial majority of the population. Similarly, more than half of respondents viewed Russia as heading in the right direction, a slight drop compared with the 2014-18 period but still higher than at any point during his first two presidential terms.

Previous research has shown that Putin's popular legitimacy has consistently rested on three factors: the performance of the economy; a strong projection of Russian interests abroad; and the maintenance of political stability. ${ }^{2}$ When the rapid economic growth of the 2000 s began to slow in the early 2010s, the incorporation of Crimea into the Russian Federation in 2014 and a more assertive foreign policy led to a temporary rebound in Putin's approval ratings. But maintaining stability in the long-term would require a resolution to the question of how to manage the end of his fourth term as president in 2024. The constitutional proscription on presidents serving more than two consecutive terms would rule him out of contention - the same dilemma he had faced in 2008 after his first eight years in the Kremlin. Then, he had

2 Derek S. Hutcheson and Bo Petersson, "Shortcut to Legitimacy: Popularity in Putin's Russia", Europe-Asia Studies 68, no. 7 (2016): 1107-1126. 


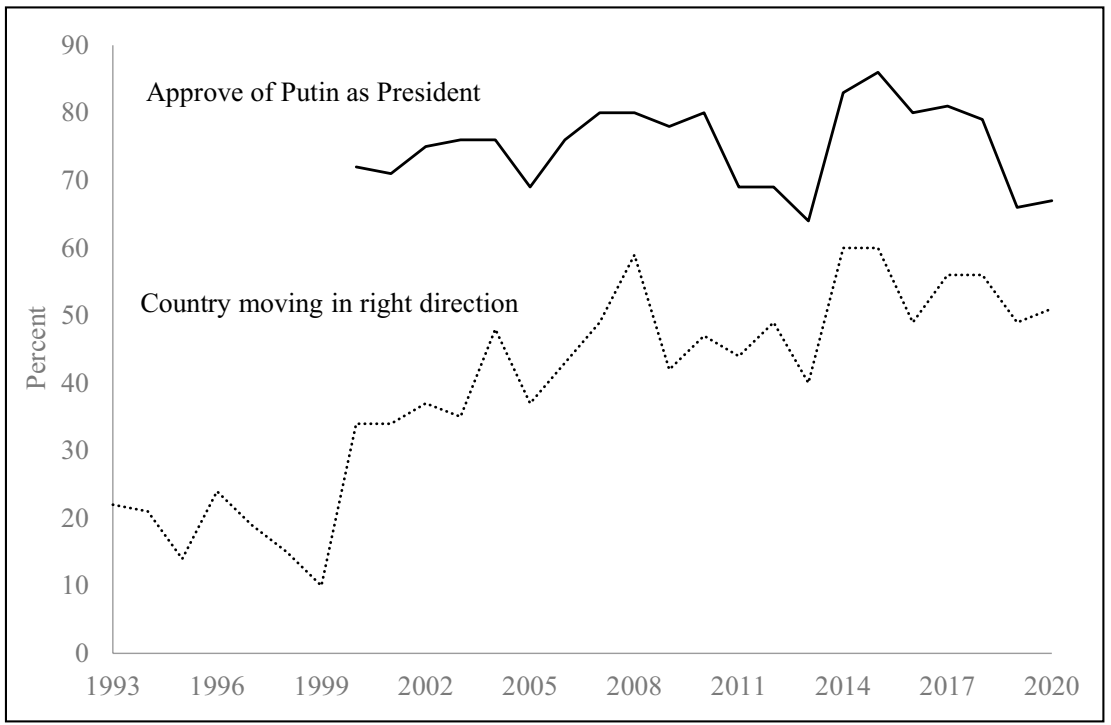

FIGURE 1 Perceptions of Putin and government popularity

The questions were: 'Overall, do you approve or disapprove of Vladimir Putin's actions as President of Russia?' and 'Overall, is the country moving in the right direction or going down the wrong path?'. The estimates for early 2020 are the average of January, February and March.

SOURCE: LEVADA CENTER, “ODOBRENIE DEYATEL'NOSTI VLADIMIRA PUTINA", HTTPS://WWW.LEVADA.RU/INDIKATORY/ (ACCESSED 9 JULY $2020)$.

stepped down in favor of Dmitrii Medvedev and returned to the presidency at the next election in 2012, after serving as Medvedev's prime minister in the interim. Would he repeat this maneuver in 2024, stepping back temporarily with a view to returning in the future? Alternatively, would he endorse a long-term preferred successor, and/or attempt to remain the center of Russian politics, outside the presidency? As a politician whose reputation was built on guaranteeing stability, his ability to continue to deliver on this would be dependent on controlling intra-elite competition for the possible succession.

The factors constraining Putin were not unusual in international terms. Term limits on presidential office exist in many countries in the world (most famously, since 1951, in the United States). They often make it difficult for outgoing presidents to maintain their political influence late into their final terms in office, as the knowledge that they will not be continuing encourages opponents to await a change of leadership. The majority of presidential systems that emerged in the 'third wave' of democratization included presidential term limits, as part of the bargaining process between competing political groups. Yet over the last 20 years, it has become apparent that there are a variety of 
means by which such limits can be amended, bypassed or ignored. ${ }^{3}$ Around a third of presidents this century who have been constitutionally prevented from standing again for office - particularly in Latin America, Africa and former Soviet States - have found ways of overcoming term limits, ${ }^{4}$ and generally by legal means rather than extraconstitutional actions. ${ }^{5}$

In Russia, public opposition to the abolition of term limits fell between Putin's return to office in 2012 and his re-election in 2018, particularly amongst those who expected to benefit economically from his continued tenure. ${ }^{6}$ Yet unlike several other post-Soviet states, the removal of the two consecutive term limit had not previously reached the mainstream political agenda, despite the fact that the pro-Kremlin United Russia party had held a constitutionamending two-thirds majority in the State Duma for three of the last four parliamentary periods.

The question of whether he would amend the constitution to redefine the presidency was addressed to Putin directly at his December 2019 annual press conference. Choosing his words carefully, he responded that 'it is my belief that we do not have to change the Constitution, I mean adopt a new one. However, he qualified that bold statement by mentioning that some aspects of the existing constitution - including the 'two consecutive terms' clause - could advantageously be amended, but that constitutional reform should take place only after 'a meaningful debate within society' and be 'carried out with extreme caution:?

Notwithstanding this groundwork, few foresaw the dramatic move that came in his annual address (poslanie) to the Federal Assembly on 15 January 2020. ${ }^{8}$ This was his sixteenth such address since 2000 , and it began as a routine

3 Alexander Baturo, "Continuismo in Comparison: Avoidance, Extension, and Removal of Presidential Term Limits", in Alexander Baturo and Robert Elgie, eds, The Politics of Presidential Term Limits (Oxford: Oxford University Press, 2019): pp. 75-100.

4 Kristin McKie, "Presidential Term Limit Contravention: Abolish, Extend, Fail, or Respect?", Comparative Political Studies, 52, no. 10 (2019): 1500-1534; Mila Versteeg, Timothy Horley, Anne Meng, Mauricio Guim and Marilyn Guirguis, "The Law and Politics Of Presidential Term Limit Evasion", Columbia Law Review 120, no. 1 (2020): 173-248.

5 Javier Corrales and Michael Penfold, "Manipulating Term Limits in Latin America", Journal of Democracy 25, no. 4 (2014): 157-168; Filip Reyntjens, "Respecting and Circumventing Presidential Term Limits in Sub-Saharan Africa: A Comparative Survey", African Affairs 119, no. 475 (2020): 275-295.

6 Paul Chaisty \& Stephen Whitefield, "The Political Implications of Popular Support for Presidential Term Limits in Russia", Post-Soviet Affairs 35, no. 4: 323-337.

7 Vladimir Putin, "Bolshaya press-konferentsiya Vladimira Putin", http://kremlin.ru/events/ president/transcripts/62366 (original in Russian) and http://en.kremlin.ru/events/presi dent/transcripts/62366 (English translation) (accessed 22 January 2021).

8 Vladimir Putin, "Poslanie Prezidenta Federal'nomu Sobraniyu", 15 January 2020, http://kremlin .ru/events/president/transcripts/messages/62582 (original in Russian) \& http://en.kremlin.ru/ events/president/news/62582 (official English translation) (accessed 22 January 2021). 
set-piece on a number of worthy but relatively technical policy areas. After $5^{1}$ minutes, however, he announced a proposal for seven major principles of constitutional reform. These included such matters as an assertion of the superiority of Russian domestic constitutional law over international treaty obligations, and a 25-year prior residence requirement for presidential candidates. But the most significant proposals were that the prohibition on one person serving more than two consecutive presidential terms was to be amended (though it was somewhat vague as to how), ${ }^{9}$ and that the minimum wage and pension indexation were to be enshrined in the constitution.

The next two months saw much political drama. The long-standing government of Dmitrii Medvedev, who had been prime minister since ending his presidency in 2012, immediately resigned. ${ }^{10}$ By mid-March, the constitutional amendments had been debated and passed conditionally into law. ${ }^{11}$ In the final package of amendments, ${ }^{12}$ the most significant reform was one that had not even been in the first draft: a new article in the constitution (Art 81.3-1), proposed in a carefully choreographed last-minute intervention by United Russia State Duma Deputy Valentina Tereshkova, ${ }^{13}$ that the two-term limit should

$9 \quad$ Putin merely stated in the speech that 'people [were] discussing the constitutional provision' that limited presidents to two consecutive terms, and that he 'support[ed] and share[ed] this view' but did 'not regard this as a matter of principle'. Though it was not entirely clear what view he supported and shared, the initial version of the bill sent to the State Duma a week later proposed to remove removal of the word 'consecutively', to create an overall two-term limit for an individual in a lifetime. At first appearance, this appeared to rule him out from continuing in office, until a further amendment exempting past presidential terms from the count was proposed during the State Duma debate (as detailed below).

10 "Ukaz o Pravitel'stve Rossiiskoi Federatsii", Decree N14, 15 January 2020, Rossiiskaya Gazeta, https://rg.ru/2020/o1/15/ukaz-dok.html (accessed 22 January 2021). Medvedev was moved to the hitherto non-existent post of deputy chairman of the Security Council, and replaced as prime minister by Mikhail Mishustin, the director of the Federal Tax Service.

11 On 20 January, a draft of the reform bill was sent to the State Duma prior to its first reading. In parallel, Putin established a working group to collate and assess amendments to the draft bill. Its proposals informed the second, expanded version of the bill sent to the State Duma on 2 March 2020, which was subsequently debated, amended and passed in second and third readings on 10 and 11 March 2020 respectively. By 14 March it had been signed into law.

12 Constitutional Amendment Act, "Zakon Rossiiskoi Federatsii o popravke k Konstitutsii Rossiiskoi Federatsii ot 14 marta 2020 g. N 1-FKZ 'O sovershenstvovanii regulirovaniya otdel'nykh voprosov organizatsii i funktsionirovaniya publichnoi vlasti'” No. 1-FKZ, 14 March 2020, published in Rossiiskaya Gazeta, 16 March 2020, https://rg.ru/2020/o3/16/ popravka-v-konstituciyu-dok.html (accessed 22 January 2021).

13 Tereshkova, a former cosmonaut, was the first woman in space in 1963. A transcript of her speech can be read at State Duma, "Stenogramma zasedanii 10 marta 2020", 
apply to a current or former president 'without taking into account the number of terms during which he held and (or) holds this position at the time the amendment to the constitution'. In other words, any presidential terms that preceded the changes would be ignored for the purposes of counting the number of terms an individual had served. Thus Putin (and, theoretically, Medvedev) could commence up to two further terms, whilst any other future president would be limited to the two terms in his or her lifetime. ${ }^{14}$ Responding to this, Putin emphasized the need for turnover in state leadership, but agreed to accept the amendment if the Federal Assembly voted for it and the Constitutional Court found it legal (which both duly did). ${ }^{15}$

Apart from this, the final list of changes to the constitution amounted to a raft of 206 separate changes that rewrote almost two-thirds of the amendable articles of the constitution. The package was a pot pourri of tweaks to the powers of state institutions, social guarantees and expressions of cultural conservatism. Some of the additions had ideological overtones, including a reference to Russia's Christian heritage, the Russian Federation as the successor state to the Union of Soviet Socialist Republics (USSR) and an emphasis on 'traditional family values'. Alongside these changes were a myriad of other small alterations, some of which were simply procedural, and others of which may have more significance in the future. ${ }^{16}$

\section{3}

\section{Campaign and Electoral Framework}

Amending the constitution does not require a public vote; ratification by two-thirds of the State Duma, three-quarters of the Federation Council, and

10 March 2020, http://transcript.duma.gov.ru/node/5430/ and viewed at http://duma.gov .ru/multimedia/video/meetings/53170/ (accessed 22 January 2021).

14 A similar device was used in the late 1990s and early 2000 s to repeatedly reset longstanding governors' first terms and allow them to stand for re-election.

15 Constitutional Court of the Russian Federation, "Zaklyuchenie Konstitutsionnogo Suda RF ot 16.03.2020 N 1-Z 'O sootvetstvii polozheniyam glav 1, 2 i 9 Konstitutsii Rossiiskoi Federatsii ne vstupivshikh v silu polozhenii Zakona Rossiiskoi Federatsii o popravke k Konstitutsii Rossiiskoi Federatsii “O sovershenstvovanii regulirovaniya otdel'nykh voprosov organizatsii i funktsionirovaniya publichnoi vlasti”, a takzhe o sootvetstvii Konstitutsii Rossiiskoi Federatsii poryadka vstupleniya v silu stat'i 1 dannogo Zakona v svyazi s zaprosom Prezidenta Rossiiskoi Federatsii”, 16 March 2020, http://publication.pravo.gov .ru/Document/View/ooo120200316o037 (accessed 22 January 2021).

16 For more detailed analysis of the reforms and their significance, see Teague, "Russia's Constitutional Reforms of 2020" and Lauri Mälksoo, "International Law and the 2020 Amendments to the Russian Constitution", American Journal of International Law 115, no. 1 (2021): 78-93. 
two-thirds of the regional legislatures (all of which were achieved with ease in March 2020) is sufficient. Nonetheless, Putin had announced from the outset that a consultative vote would take place to legitimize the changes, and the Constitutional Amendment Act made the changes conditional upon receiving a simple majority of support in an 'all-Russian vote'. ${ }^{17}$ What was not part of the original plan was the COVID-19 pandemic. On 17 March 2020, Putin signed a decree setting the date of the vote for 22 April 2020 (on what would, symbolically, have been the 15 oth birthday of Soviet revolutionary Vladimir Lenin). But as Russia's infections began to increase exponentially, this swiftly had to be postponed. In his decree setting the new date of 1 July, Putin made it a condition of the vote that it was held in line with sanitary norms to protect from Covid-19. In practice, this meant that there would be a week-long early vote, in addition to polling day itself.

The vote fell into a fuzzy legal category. Though commonly described as a 'referendum', technically under Russian law it was an 'All-Russian vote' (obshcherossiiskoe golosovanie), and regulated by ad hoc legislation..$^{18}$ The general parameters were mandated in the Constitutional Amendment Act, set in motion by a presidential decree ${ }^{19}$ and fleshed out by a Central Electoral Commission resolution. ${ }^{20}$ Amongst other things, this meant that there was no official 'yes' or 'no' campaign, and that formal campaigning was replaced by a process of 'informing the public'. There was weaker financial regulation than in

17 Constitutional Amendment Act, Art.3·3-3.5.

18 The word 'referendum' is generally used in this article interchangeably with 'public vote' to describe the ballot, even though it did not fall into this category according to Russian law. The Constitutional Amendment Act made the changes conditional on public approval, even if this was not normally necessary to alter the constitution - so it was more than simply a consultative vote, but less than a formal referendum.

19 President of the Russian Federation, "Ukaz Prezidenta Rossiiskoi Federatsii ‘O naznachenii obshcherossiiskogo golosovaniya po voprosu odobreniya izmenenii v Konstitutsiyu Rossiiskoi Federatsii", No. 188, 17 March 2020, Official State Information Portal for Legal Information, http://publication.pravo.gov.ru/Document/View/ooo1202003170038 (accessed 22 January 2021); replaced by “Ukaz Prezidenta Rossiiskoi Federatsii 'ob opredelenii daty provedeniya obshcherossiiskogo golosovaniya po voprosu odobreniya izmenenii v Konstitutsiyu Rossiiskoi Federatsii"', No. 354, 1 June 2020, ibid., http://publication .pravo.gov.ru/Document/View/ooo1202006010049 (accessed 22 January 2021).

20 Central Electoral Commission of the Russian Federation (CEC-RF), "Postanovleniye ot 20 marta 2020 g. N 244/1804-7 'O Poryadke obshcherossiiskogo golosovaniya po voprosu odobreniya izmenenii v Konstitutsiyu Rossiiskoi Federatsii", 2o March 2020. Published in its original form in Vestnik Tsentral'nogo Izbiratel'noi Komissi Rossiiskoi Federatsii No. 3 (2020), and subsequently amended by CEC-RF resolutions N 245/1815-7 (27 March 2020); N 25o/184O-7 (2 June 2020); N 253/1871-7 (19 June 2020); and N 254/1879-7 and N 255/1885-7 (23 June 2020). Final text available from http://cikrf.ru/analog/constitution-voting/ poryadok-obshcherossiyskogo-golosovaniya.php (accessed 22 January 2021). 
a formal referendum. Observers were accredited though the Public Chamber rather than independent organizations, and - ostensibly on the back of the COVID-19 crisis - early voting was extended over the week prior to polling day. Voting could take place in an 'adjoining area or public space' if the sanitary norms could not be met - which meant outdoor participation in some places. In Moscow and Nizhny Novgorod, it was possible to vote electronically, on an experimental basis.

The main campaign messages downplayed the political amendments to the constitution (in particular, the presidential term reset), and emphasized instead the social, cultural and sovereignty questions around which it was easier to mobilize public support. The reset was also virtually ignored in the Central Electoral Commission's information booklet and poster, save for a small-font legal footnote. ${ }^{21}$ Nor did Putin mention it in his sole address to the nation on the amendments - though he did briefly concede the logic behind it in a separate television interview in the week before the voting started, when he stated that, without it, 'eyes [would] start prowling in search of possible successors'. ${ }^{22}$ In other words, keeping open the option of standing again would prevent him becoming a 'lame-duck' president in the eyes of his elite.

Opposition to the proposals was muted. One problem was the limited campaigning opportunities caused by the pandemic. Public rallies were difficult to organize with COviD-related restrictions on gatherings. Such resistance as there was to the changes relied partly on online campaigns and memes. ${ }^{23}$ In the absence of formal 'yes' and 'no' campaigns, there was also limited platform for debate. But the lack of opposition also reflected a divided anti-Kremlin political spectrum, as well as the nature of the reforms. The conflation of so many different issues in a single 'yes/no' question made it difficult to separate out the different strands. By opposing political restructuring and the prolongation of Putin's rule, opponents were also campaigning against enshrining social guarantees and nationalist-patriotic rhetoric that they in many cases supported.

A second problem for the opposition was that the fallback position in the event of a 'no' vote - the continuation of the existing super-presidential constitution was hardly a better option. They had spent the last quarter-century blaming

21 Central Electoral Commission, Popravki k Konstitutsii Rossiiskoi Federatsii (2020), http://cikrf.ru/analog/constitution-voting/informatsionnye-materialy/makety/Booklet _Popravki_k_Constitution_o8_o6.pdf (accessed 21 January 2021): 12. tass.ru/politika/8782125 (accessed 3 July 2020).

23 The Moscow Times, "Russia Wields Memes to Protest Putin's Constitutional Reforms", The Moscow Times, 23 June 2020, https://www.themoscowtimes.com/2020/o6/23/russia-wields -memes-to-protest-putins-constitutional-reforms-a70670 (accessed 21 January 2021). 
Russia's ills on its power structures. This dilemma was epitomized early in the process when one of the more prominent extra-parliamentary opposition campaigners, Alexei Naval'nyi, refused to participate in anti-reform protests. He reasoned that 'the constitution of the Russian Federation is loathsome ... there is no need to defend it' and advocated boycotting the vote. ${ }^{24}$ Of the four parties in the State Duma, only the Communist Party of the Russian Federation (CPRF) did not support the original bill. It abstained in parliament, ${ }^{25}$ and eventually issued a statement encouraging its voters to oppose the reforms outright. ${ }^{26}$

Polling day was set for 1 July 2020, but early voting - both at polling stations and at home locations - commenced on 25 June. On the eve of the vote, a grandiose military parade was held to commemorate the $75^{\text {th }}$ anniversary of victory in the Great Patriotic (Second World) War. Held with great pomp and ceremony in Red Square, it provided an emblematically patriotic backdrop for the vote. Figures announced sporadically by the Central Electoral Commission in the week prior to polling day indicated a steady number of people voting each day prior to 1 July - on average, just over 9 percent of the electorate per day. By the time the official polling day began, the majority of people had already voted. ${ }^{27}$

24 Aleksei Naval'nyi, Twitter post, 17 January 2020, https://twitter.com/navalny/sta tus/1218144227894259718 (accessed 9 July 2020).

25 G.A. Zyuganov, "Rossii nuzhna Konstitutsiya spravedlivosti i narodovlastiya!", 10 March 2020, https://kprf.ru/party-live/cknews/192372.html (accessed 9 July 2020).

26 G.A. Zyuganov, "KPRF - za Konstitutsiyu spravedlivosti i narodovlastiya. Zayavlenie Prezidiuma TsK KPRF”, Krasnaya Liniya, 4 June 2020, https://www.rline.tv/news/2020 -o6-o4-kprf-vystupila-protiv-prinyatiya-popravok-v-konstitutsiyu/ (accessed 1o August 2020).

27 Direct daily comparison is impossible due to the figures being announced at different times of the day and with different levels of precision in Central Electoral Commission press conferences. The approximate cumulative turnout levels after each day of voting were 9.20 percent (25 June); 19.49 percent (26 June); 28.46 percent (27 June); 37.20 percent (28 June) and 45.70 percent (29 June). No figure was announced for 30 June, but at 1oam on 1 July (two hours after the polls opened on the final day of voting), turnout was reported to be 55.27 percent, the vast majority of whom had presumably voted before polling day. A summary of the CEC reports prior to 1 July can be found at "Golosovanie po popravkam k Konstitutsii: Khronika i poslednie dannye”, Kommersant' 25 June and 2 July 2020, https:// www.kommersant.ru/doc/4391489?from=doc_vrez (accessed 13 July 2020). The figure for the morning of 1 July comes from Ella Pamfilova/Central Electoral Commission, “Informatsionnyi tsentr TsIK Rossii: osnovnoi den' golosovaniya po popravkam v Konstitutsiyu Rossiiskoi Federatsii", 1 July 202O, http://cikrf.ru/news/cec/46727/ (accessed 13 July 2020). 


\section{The Regional Results}

The headline rate of support for the reforms was impressive. On a 67.97 percent turnout (only around 12-13 percent of whom voted on polling day itself), 78.92 percent of votes were reported in favor of the amendments to the constitution. The revised constitution duly came into force on 4 July 2020 , once the results were officially certified. As is customary in Russian elections, turnout was high in a select group of national republics and regions well known for their 'machine' politics. In 15 of the 85 regions, turnout was above 8 o percent, and as high as 95 percent in Chechnya. At the other end of the scale, there were nine regions in which fewer than half the voters turned out to vote. The lowest turnout was in Kamchatka Krai, which returned a turnout of 44.06 percent. The overall level of turnout exceeded that in three of the last six presidential elections.

Figure 2 shows a map of the percentage share of votes cast in favor of the amendments (expressed as a share of those voting) across the Russian Federation. Only one of the 85 regions voted against the changes - the sparsely populated Nenets Autonomous District on the Arctic coast, where the 'no' vote

TABLE 1 The result of the 2020 constitutional referendum

\begin{tabular}{lrr}
\hline & \multicolumn{1}{l}{ Votes } & Percent \\
\hline Yes & $57,747,288$ & 77.92 \\
No & $15,761,978$ & 21.27 \\
Valid votes & $73,509,266$ & 99.18 \\
Invalid votes & 604,951 & 0.82 \\
Total votes & $74,114,217$ & 100.00 \\
Registered voters & $109,190,337$ & \\
Turnout & & 67.97 \\
\hline
\end{tabular}

Source: Central Electoral Commission ${ }^{\mathrm{a}}$

a Central Electoral Commission of the Russian Federation, "O rezul'tatakh obshcherossiiskogo golosovaniya po voprosu odobreniya izmenenii v Konstitutsiyu Rossiiskoi Federatsii", No. 256/1888-7, 3 July 2020, http://vestnik.cikrf.ru/vestnik/documents/ decree_of_cec/46746.html (accessed 14 August 2020). A regional table of the results is available at http://www.vybory.izbirkom.ru/region/region/izbirkom?action=sho w\&root=1\&tvd=100100163596969\&vrn=100100163596966\&region=o\&global=1\&sub _region=o\&prver=o\&pronetvd=null\&vibid=100100163596969\&type $=465$ (accessed 14 August 2020). Notwithstanding the definition of turnout in the Constitutional Amendment Act (Art. 2.25) as the number of ballot papers in the ballot box, the official figure follows the usual Russian practice of determining turnout by the number of ballot papers given out, and the percentage vote shares from the number of ballot papers handed in (which is slightly less). 


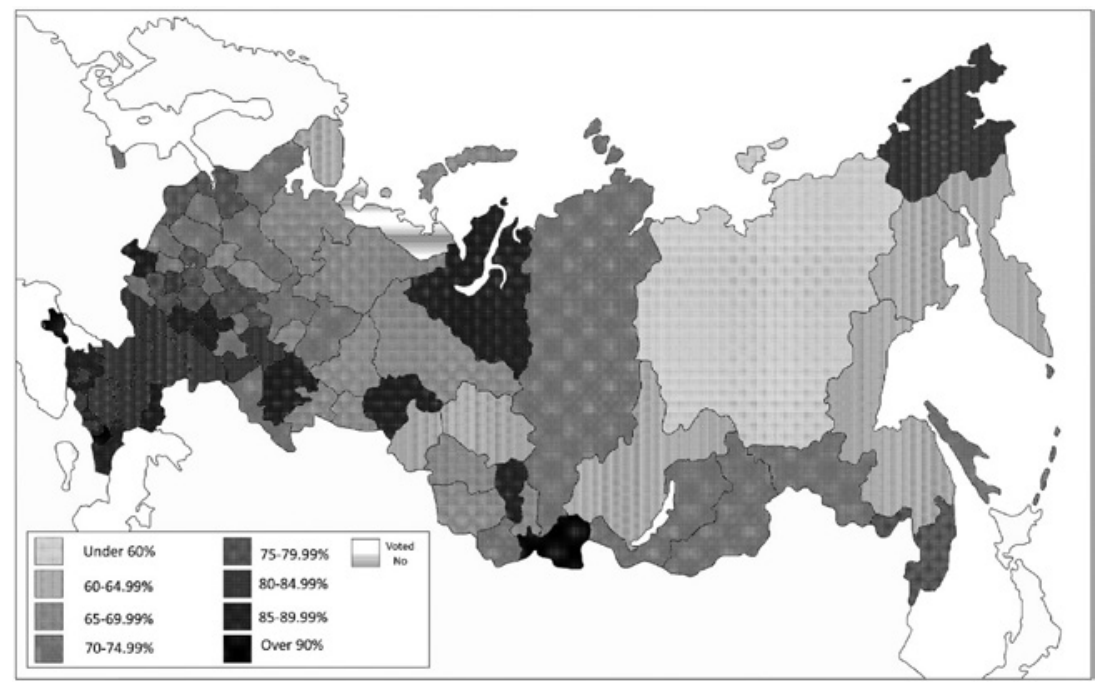

FIGURE 2 Percentage 'yes' vote (as proportion of votes cast) by region, July 2020 SOURCE: AUTHORS' ANNOTATION OF RESULTS FROM CENTRAL ELECTORAL COMMISSION OF THE RUSSIAN FEDERATION, "O REZUL'TATAKH OBSHCHEROSSIISKOgo gOLOSOVANIYA".

was 55.25 percent. Rather than opposition to the reforms per se, it was thought that this was mainly an expression of protest about a May 2020 proposal to merge the Autonomous District into Arkhangelsk Province. ${ }^{28}$ All the remaining 84 regions voted in favor. Support levels ranged from 58.3 percent in the Siberian Republic of Sakha (Yakutia) to a spectacular 97.9 percent in Chechnya and 96.8 percent in Tuva. No less than 30 of the 85 regions reported a 'yes' vote above 8 o percent of the votes cast, as the darker shades in Figure 2 show. It was necessary only to obtain a majority of votes cast to ratify the changes - but so high was the vote in favor that the amendments were endorsed by an absolute majority of the entire registered electorate $-5^{2.9}$ percent - even accounting for non-voters.

28 Nenets Autonomous District is one of three such ethnic districts in Russia that are simultaneously sub-parts of larger provinces (in this case, Arkhangelsk) as well as federal subjects in their own right. The governor of the Nenets Autonomous District confirmed in September 2020 that the merger was off the agenda indefinitely as 'it was clear what signals the residents sent' [RIA Novosti, "Yurii Bezdudnyi: vopros ob"edineniya NAO s Arkhangel'skoi oblast'yu zakryt", 22 September 2020, https://ria.ru/20200922/ obedinenie-1577567605.html (accessed 5 October 2020)]. 
This generally strong expression of approbation for the constitutional amendments betrays a strong regional variation in the results. As Figure 2 shows, areas south-west of Moscow had particularly high 'yes' vote shares, especially in the far south and the Caucasus region. The ethnic republics of the mid-Volga region, similarly, were hotbeds of support for the amendments, as were several other regions with titular ethnic designations: the Republic of Tyva (on the border with Mongolia), and the far north autonomous districts of Yamalo-Nenets and Chukotka. The provinces of Tyumen' and Kemerovo in Siberia also stood out. With these exceptions, generally the Siberian and Pacific coast regions had lower 'yes' votes than most of the western and southern parts of the Russian Federation - though this was a relative concept, as their 'yes' totals were generally between 60 and 75 percent.

Previous national elections, most recently the 2018 presidential election, have been notable for wide disparities in the levels of turnout across the regions, which have been strongly correlated with party support levels. ${ }^{29} \mathrm{In}$ the 2018 election, turnout was highest in the regions which were most supportive of Putin, and lowest in regions where his support was weakest. This pattern was also evident in the 2016 Duma election, when it appeared to be a conscious strategy on the part of the Putin-supporting United Russia party to mobilize voters where their support was likely to be high and to demobilize voters in areas where their support was assumed to be low (encouraging them to abstain rather than to vote instead for the opposition). ${ }^{30}$ This is a familiar strategy among governing parties in authoritarian systems and is most effective when parties play a central role in encouraging (or discouraging) voters to turnout. ${ }^{31}$

One possibility is therefore that differential turnout played a role in explaining the high 'yes' vote for the constitutional changes. If this explanation were to hold, we would expect the regions with higher turnout to return a larger 'yes' vote as a proportion of those that voted, net of other things. Similarly, we would also expect that previous support for Putin and the pro-Kremlin United Russia Party across the regions would also translate into support for a 'yes' vote. This results in two hypotheses. The first hypothesis tests the possibility that

29 See Derek S. Hutcheson and Ian McAllister, "Putin versus the Turnout? Mapping the Kremlin's 2018 Presidential Election Support", Russian Politics 3, no. 3 (2018): 333-358.

30 See Derek Hutcheson and Ian McAllister, "Explaining Party Support in the 2016 Russian Duma Election", Russian Politics 2, no. 4 (2017): 454-481; Ian McAllister and Stephen White (2017), "Demobilizing Voters: Election Turnout in the 2016 Russian Election", Russian Politics 2, no. 4: 411-433.

31 See Joao Cancela and Benny Geys, "Explaining Voter Turnout: A Meta-Analysis of National and Subnational Elections", Electoral Studies 42, no. 3 (2016): 264-275. 
turnout in the referendum itself directly led to the high 'yes' vote. A second hypothesis relates the 'yes' vote directly to the vote for Putin in the 2018 presidential election, and to the United Russia Party in the 2016 Duma election. The reasoning is that a person who is favorably disposed towards the president and to the 'party of power' supported by him - is more likely to be in favor of constitutional changes that are recommended by these actors.

$\mathrm{Hr}$ The higher the turnout in a region, the higher the referendum 'yes' vote.

$\mathrm{H}_{2}$ The higher the vote for Putin in the 2018 presidential election and United Russia in the 2016 Duma election in a region, the higher the referendum 'yes'vote.

While opposition to the reforms during the campaign was relatively muted, there have been parties and candidates who have opposed Putin in previous elections. Most notably, the CPRF in 2016 and the CPRF's candidate in the 2018 presidential election, Pavel Grudinin, were vocal critics of Putin's policies. ${ }^{32}$ We might predict that regions that returned a higher vote for the CPRF in 2016 or for Grudinin in the 2018 election would return a higher 'no' vote. This expectation leads to a third hypothesis:

$H_{3}$ The higher the vote for the CPRF in the 2016 Duma election and for Grudinin in the 2018 presidential election in a region, the higher the referendum 'no' vote.

To test these three hypotheses, the results of the 2020 referendum in each of the 85 regions (plus the total votes cast by Russians, resident abroad, counted collectively) were matched to the results for the 2016 Duma and 2018 presidential elections. In addition, in order to take into account the characteristics of the regions and not least their geographic dispersion and distinctive characteristics, we include in the analyses the time zone (measured by \pm hours UTC, as a proxy for distance from Moscow), density (measured by 100 persons per square kilometer), and whether or not the region was an autonomous republic. The variables are listed in Table 2 together with their scoring, means and standard deviations. The dependent variables are the percentage 'yes' and 'no'

32 See Archana Upadhyay, "Decoding Russia's 2018 Presidential Elections", International Studies 55, no. 3 (2018): 271-277. 
TABLE 2 Variables, definitions and mean

\begin{tabular}{llrr}
\hline & Scoring & Mean & St Dev \\
\hline Yes vote, 2020 referendum & Percent & 75.82 & 9.50 \\
No vote, 2020 referendum & Percent & 23.29 & 9.37 \\
Invalid vote, 2020 referendum & Percent & 0.89 & 0.30 \\
Turnout, 2020 referendum & Percent & 66.09 & 13.49 \\
Putin vote, 2018 election & Percent & 76.48 & 6.52 \\
United Russia vote, 2016 election & Percent & 51.59 & 14.13 \\
Grudinin vote, 2018 election & Percent & 12.07 & 4.41 \\
CPRF vote, 2016 election & Percent & 14.03 & 4.70 \\
UTC & Hours & 4.66 & 2.53 \\
Density & 10o persons & 144.15 & 722.51 \\
& per sq. km & & \\
Republic & 1 yes, o no & 0.26 & 0.44 \\
\hline
\end{tabular}

$\mathrm{N}=86$ (85 Russian regions + voters outside the Russian Federation [cumulative total]).

votes in the 2020 referendum. The analyses were conducted using ordinary least squares regression.

The first analysis, shown in Table 3, tests the first two hypotheses. The dependent variable is the 'yes' vote in the referendum. Since the dependent variable is a percentage, the partial coefficients can be interpreted as the impact of a one-unit change in the independent variable on the percentage 'yes' vote. The results are presented in the form of two models, corresponding to the two hypotheses. The first model tests the hypothesis that the turnout was a major factor in promoting the 'yes' vote, in line with what occurred in both the 2016 and 2018 elections. The second model tests the second hypothesis by adding in the vote for Putin in the 2018 presidential election and the vote for the United Russia Party in the 2016 Duma election.

The results provide strong support for the first hypothesis, with turnout emerging as a major predictor of the 'yes' vote. The partial coefficient for turnout $(\beta)$ suggests that each extra one percentage increase in turnout in a region increased the 'yes' vote by almost o.6 percent, net of other things, a substantial figure. For example, comparing two regions with very different levels of turnout shows how important it was to the outcome of the election. The Arkhangelsk Province had a turnout of just over 50 percent, while the Tambov Province had a turnout of just over 80 percent. The analysis in Table 3 suggests that the 'yes' 
TABLE 3 Predicting the 'yes' vote in the 2020 referendum

\begin{tabular}{lcccc}
\hline & \multicolumn{2}{c}{ Model 1 } & \multicolumn{2}{c}{ Model 2 } \\
& $\beta$ & $($ SE $)$ & $\beta$ & $($ SE $)$ \\
\hline Turnout, 2020 referendum & $.59^{* *}$ & $(.04)$ & $.45^{* *}$ & $(.04)$ \\
Putin vote, 2018 election & - na - & & $.39^{*}$ & $(.16)$ \\
United Russia, vote 2016 election & - na - & & .03 & $(.09)$ \\
Controls & & & & \\
UTC & -.31 & $(.22)$ & -.04 & $(.23)$ \\
Density & -.01 & $(.01)$ & -.04 & $(.01)$ \\
Republic & .41 & $(1.25)$ & -.60 & $(1.31)$ \\
Constant & 38.54 & & 15.32 & \\
Adj. R-squared & .74 & & .77 & \\
\hline
\end{tabular}

${ }^{* *}$, statistically significant at $<$ p.o1, ${ }^{*} \mathrm{p}<.05 . \mathrm{N}=86$ Russian regions. Ordinary least squares regression analysis predicting the 'yes' vote in the 2020 referendum, measured as a percentage.

vote in Tambov would be just under 18 percent higher than in Arkhangelsk due solely to the effect of differential turnout. (In reality, it was 21.6 percent higher.) We therefore find strong support for hypothesis one.

The second model in Table 3 tests the hypothesis that the prior vote for Putin in 2018, or the United Russia Party in 2016, was a significant factor in increasing the 'yes' vote in the referendum. There is some limited support for this: an increased vote for Putin in the presidential election increased the 'yes' vote by around o.39 percent, net of other things. At the same time, with these additional factors taken into account, the impact of turnout declines to 0.45 , but remains highly significant and easily the most important variable in the model. There is therefore some support for hypothesis two. Finally, none of the control variables are statistically significant, suggesting that the geographic location of the region, its political status (as a republic, province or autonomous region) or its population density had no effect per se on how the region voted in the referendum, net of other effects. This is significant because some of the national republics (especially those in the North Caucasus) are known for their high turnouts and pro-Kremlin results. Thus, it is not the holding of republic status per se which contributes to this, but the particular internal political nature of some of them.

The third hypothesis concerns the factors that may have affected the 'no' vote, either through a vote for the CPRF candidate Pavel Grudinin in the 2018 
election or for the CPRF party in the 2016 election. There is strong support for this hypothesis. The results in Table 4 show that the vote for Grudinin was a significant predictor of the 'no' vote in a region in the referendum. Each extra one percent increase in Grudinin's 2018 vote boosted the 'no' vote in the same region by 1.1 percent in 2020. However, since Grudinin attracted only 12 percent of the vote in the presidential election, the overall impact of his erstwhile supporters on the referendum result was not as substantial as the impact of differential turnout shown earlier. Nevertheless, the results support hypothesis three.

The results therefore provide support for all three hypotheses. Which of the various effects was most important in shaping the result? As we have found in other analyses of recent Russian elections, differential turnout was by the far most important. Whether it was a conscious strategy on the part of the Putin campaigners and strategists or simply a continuation of a trend started some elections before, regions with higher turnout delivered a significantly higher 'yes' vote compared to regions with lower turnout levels. Next in importance is a 'no' vote stemming from support for Pavel Grudinin in the 2018 election. This is followed by the effect of voting for Putin in 2018 on the 'yes' vote. Overall, turnout mattered more than anything else in shaping the referendum vote, but how a region voted for candidates in the presidential election also mattered.

TABLE 4 Predicting the 'no' vote in the 2020 referendum

Model 1

B

(SE)

$\begin{array}{lcc}\text { Grudinin vote, } 2018 \text { election } & 1.10^{* *} & (.28) \\ \text { CPRF vote, 2016 election } & .21 & (.23) \\ \text { Invalid vote, 2020 referendum } & -\mathrm{na}- & \\ \text { Controls } & & \\ \text { UTC } & .05 & (.38) \\ \text { Density } & .01 & (.01) \\ \text { Republic } & -3.27^{*} & (1.81) \\ \text { Constant } & 7.34 & \\ \text { Adj. R-squared } & .38 & \\ & & \\ \text { **, statistically significant at }<\text { p.o1, * } \mathrm{p}<. \text {.05. N }=86 \text { Russian } \\ \text { regions. Ordinary least squares regression analysis predicting the } \\ \text { 'no' vote in the 2020 referendum, measured as a percentage. }\end{array}$


As has become customary in Russian elections, the Kremlin's success in gaining strong vote shares was accompanied by questions from observers and opposition politicians about how they had been obtained. It is rare for such actors to praise the electoral process, but their criticisms in 2020 were more vocal than in federal elections to the 2016 State Duma and to the presidency in 2018. Criticisms of the fairness of the referendum focused on three aspects: the difficulty of keeping control over a voting process that was drawn out over several days; allegations of administrative pressure on state employees to vote; and statistical anomalies in some districts' results.

On the procedural questions, it has already been noted that the vote was regulated from the start by ad hoc legislation, rather than the official referendum law. In addition, the pandemic led to exceptional voting procedures, which led to concerns about transparency and procedural exactitude. The Golos ('Voice') electoral rights movement noted the limited scope for a proper debate in the absence of campaign groups, and was also critical of some of the basic organizational aspects. For example, the hours of opening of polling stations were decided less than two days before voting began, ${ }^{33}$ and the early (positive) results from the far eastern regions were already being announced on television by the CEC while the polls in the western time zones of Russia were still open. ${ }^{34}$

On the question of pressure on state employees, the creation of multiple channels for participation over several days - including early voting, open-air voting and special polling stations at enterprises - was ostensibly an inclusive measure. But aside from making it difficult to keep constant observation of ballot boxes and voting procedures, Golos also noted reports of pressure being put on state and enterprise employees to vote under the watchful eyes of

33 The original version of the law, which was passed before the covid-19 restrictions, made provision for early voting for only a limited number justifiable reasons [Central Electoral Commission of the Russian Federation (CEC-RF), "Postanovleniye ot 20 marta 2020 g". Art. 10.5]. In the revised version approved on 2 June 2020, early voting from 25 to 30 June was provided for, with hours of polling to be determined locally. On 23 June (two days before polls opened), this was changed to a standardized $8 \mathrm{am}$ to $8 \mathrm{pm}$ local time, across the country [Central Electoral Commission of the Russian Federation, "O vnesenii izmenenii v Poryadok obshcherossiiskogo golosovaniya po voprosu odobreniya izmenenii v Konstitutsiyu Rossiiskoi Federatsii", No. 255/1885-7, 23 June 2020, http://vestnik.cikrf.ru/ vestnik/documents/2020/06/19/46496.html (accessed 22 January 2021)].

34 Golos movement, "Predvaritel'noye zayavleniye po itogam obshchestvennogo nablyudeniya za khodom obshcherossiiskogo golosovaniya po izmeneniyu Konstitutsii", https://www.golosinfo.org/articles/144477 (accessed 22 January 2021). 
their employers, mirroring similar reports from previous elections. ${ }^{35}$ In cases of open-air voting, questions were raised about how secret the ballot could be in situations whereby car bonnets and tree stumps were sometimes used as makeshift polling tables.

When it came to the results, the strong correlation between the 'yes' vote and early turnout rates, but not with turnout on polling day itself (at least from 1oam onwards), was interpreted by some observers as evidence that early voters had been coerced. ${ }^{36}$ Whilst this is one possible explanation, research has shown that early voters in other countries also tend to be older and more conservative. ${ }^{37}$ Given that the reforms were more popular amongst older voters (who were also in the pandemic risk group), there may have been a greater likelihood that they would vote early or at home. Similarly, we know from survey evidence that those opposed to the reforms were more likely to leave it to the last day to vote, and to do so in the polling stations. ${ }^{38}$ Multicollinearity between the number of early voters and the overall turnout figure is also to be expected.

On the third question - statistical anomalies in some districts' results - the 'fingerprints of fraud' claimed by Russian electoral statisticians over successive elections were observed by the same group's analysis this time round: an above-expected number of round integers in the results, and a binominal turnout distribution..$^{39}$ Attention was also drawn to several voting districts around Russia with statistically unusual results. ${ }^{40}$

35 Arkadii Lyubarev, "Defects of Russian Elections and Ways to Overcome Them", Russian Politics 5, no. 3 (2020): 190-205.

36 Andrei Buzin, "Tsifrovye mysli o 'triumfe obshcherossiiskogo golosovaniya", Golos Movement, https://www.golosinfo.org/articles/144554 (accessed 11 August 2020).

37 Ian McAllister and Damon Muller, "Early voting, election campaigning and party advantage in Australia", Electoral Studies, $5^{2}$ (2018): 103-110.

38 The post-election survey conducted by the Levada Center indicated that those who voted on 1 July were least likely to have voted 'yes', and that a larger proportion of 'no' voters had voted at the polling station than amongst 'yes' voters [Levada Center, "Kto i kak golosoval za popravki v konstitutsiyu", Post-election survey, published 8 August 2020. N = 1617, fieldwork 24-25 July, https://www.levada.ru/2020/o8/o7/kto-i-kak-golosoval-za-popravki-v -konstitutsiyu-zavershayushhij-opros/ (accessed 22 January 2021)].

39 Dmitry Kobak, Sergey Shpilkin, \& Maxim Pshenichnikov, "Statistical fingerprints of electoral fraud?", Significance 13 (2016), 20-23; Dmitry Kobak, Sergey Shpilkin and Maxim S. Pshenichnikov, "Suspect peaks in Russia's 'referendum' results", Significance 17, no. 5: 8-9.

40 In Shalinsky district in central Chechnya, every single polling station reported the same 'yes' vote share [David Kankia, "Idealnaya pryamaya v Chechne", Golos Movement, https://www.golosinfo.org/articles/144479 (accessed 22 January 2021); official result at http://www.vybory.izbirkom.ru/region/region/izbirkom?action=show\&root=2020000 o8\&tvd=2202000757923\&vrn=100100163596966\&region $=$ o\&global=1\&sub_region $=$ o\&p rver $=0 \&$ pronetvd=null\&vibid $=2202000757923 \&$ type $=465$ (accessed 22 January 2021)] . Similar very narrow variation from the mean was observed in several districts of Dagestan, Bashkortostan and Tatarstan. In the latter, some districts in the republic's two largest 
It is worth noting that most of the known cases tended to cluster in a few regions - mainly in the north-Caucasus and mid-Volga republics - whose results have been questioned in several previous elections. Given this narrow geographical pattern, it is difficult to establish definitively if these were simply isolated cases in a few regions generally known for their electoral overproduction, or if they were the tip of a larger iceberg. Regardless of this, the main matter of concern would be whether such irregularities affected the result so materially as to render it invalid. Even the calculations of the most skeptical observers - such as physicist Sergei Shpil'kin, who speculated that many of the votes in the higher peak of turnout had been artificially augmented in the results - suggested that the constitutional changes would have passed with relative ease, albeit with fewer votes. ${ }^{41}$ But clearly the successful conduct of an election or referendum lies not only in how accurate the reported result actually is, but also in the extent to which it is acknowledged as legitimate by the public.

On this latter point, there may be more grounds for concern. After falling for many years, the number of people regarding the electoral process as 'fair and free' increased substantially in the 2018 presidential election, as the Central Electoral Commission sought to improve transparency and crack down on verifiable cases of fraud more harshly. ${ }^{42}$ This trend reversed again in the 2020 referendum. A post-election survey indicated that only 48 percent of respondents regarded the voting process to have been conducted fairly. By a majority of almost 2 to 1 , those who had not voted viewed the process as unfair/dishonest,

cities, Kazan' and Naberezhnye Chelnye, had variations of less than 1 percent in turnout and 'yes' vote shares. See, for example, the official Sovetskaya district result of Kazan', where the product of the turnout and 'yes' votes consistently came to almost exactly 50 percent of the overall electorate [http://www.vybory.izbirkom.ru/region/region/izbi rkom? action $=$ show $\&$ tvd $=100100163598025 \&$ vrn $=100100163596966 \&$ region $=0 \&$ global $=1$ \&sub_region $=0 \&$ prver $=0 \&$ pronetvd $=$ null\&vibid $=21620002480942 \&$ type $=465$ (accessed 22 January 2021)] and the Avtozavodksaya district of Naberezhnye Chelnye, where 53 of the 57 polling stations had a 'yes' vote between 79.14 percent and 79.55 percent [http:// www.vybory.izbirkom.ru/region/region/izbirkom?action=show\&tvd=100100163598025\& vrn $=100100163596966 \&$ region $=0 \&$ global $=1 \&$ sub_region $=0 \&$ prver $=0 \&$ pronetvd $=$ null $\& v$ ibid=21620002480916\&type $=465$ (accessed 22 January 2021)]. Another type of anomaly was found in the town of Klintsy in Bryansk, where almost all polling stations had elegantly symmetrical turnouts of exactly 90 and 91 percent alternately [http://www.vybory .izbirkom.ru/region/region/izbirkom?action=show\&tvd=100100163598041\&vrn=1001001 $63596966 \&$ region=o\&global=1\&sub_region $=$ o\&prver $=0 \&$ pronetvd $=$ null\&vibid $=2322000$ 1314888\&type $=465$ (accessed 22 January 2021)].

41 Sergey Shpil'kin, "Vot i vsya lyubov': Istinnye dannye 'golosvaniya' otlichayutsya t ozvuchennykh TsIKom", Novaya Gazeta, 2 July 2020, https://novayagazeta.ru/articles/2020/o7/ o2/86114-vot-i-vsya-lyubov (accessed 22 January 2021).

Hutcheson and McAllister, "Putin versus the Turnout?" 
indicating one of the reasons for their abstention. But just under a third of those who did participate also held this view. ${ }^{43}$ Given that the ultimate point of the referendum was to legitimize Putin's potential right to remain in place for many years to come, it was of crucial importance that the process of legalizing this was perceived to be legitimate by the Russian population. Yet survey evidence indicates that public - especially younger and working-age voters held substantial reservations about the fairness of the referendum.

\section{Subsequent Developments and Long-Term Significance}

The 2020 public vote on changes to the Russian constitution was significant for many reasons. In practical terms, it was another manifestation of the Kremlin's ability to deliver successful electoral mandates, in this case conducted in the middle of a pandemic. Substantively, the change that mattered most was the 'zeroing' of previous presidential terms. Even if this was downplayed in the campaign and buried amongst 205 other amendments, it opens up the prospect of the current regime continuing for potentially another decade-anda-half. This does not preclude Putin opting to exit anyway in 2024 or 2030 - but it effectively shuts down intrigue on the matter until a time of his choosing, ensuring that his powers of patronage and arbitration remain intact. While the other constitutional changes are less momentous, they leave scope for further reconfigurations in the years to come. The codification of social guarantees, conservative ideologies, family values, and a passing reference to the interests of Russians abroad, all sow the seeds for a possible conservative turn in future state policy.

In the months following the referendum, several steps were taken to put flesh on the bones of the amendments. In the autumn of 2020, the Federal Assembly considered and ratified a package of legal reforms that sought to bring civil law into line with the new constitutional provisions, amending over 100 laws and six codes, and asserting the supremacy of domestic law. ${ }^{44}$ In April 2021, a law that codified the new 25-year residence requirement and twoterm limit for presidential office was signed into force, after debate in the State Duma and Federation Council.45

43 Levada Center, "Kto i kak golosoval”.

44 Kseniya Veretennikova and Angelina Galanina, "Gosduma popravila pravovuyu vertikal", Kommersant', 28 October 2020, https://www.kommersant.ru/doc/4549588 (accessed 21 January 2021).

45 Federal Law, “O vnesenii izmenenii v otdel'nye zakonodatel'nye akty Rossiiskoi Federatsii No. 89-FZ, 5 April 2021, https://rg.ru/2021/o4/o9/zakon-dok.html, published in Rossiiskaya Gazeta, 9 April 2021 (accessed 1 July 2021). 
In the electoral sphere, some of the practical arrangements that temporarily loosened voting restrictions in the face of the pandemic have been incorporated more permanently into mainstream electoral legislation. In particular, in late July 2020 amendments were rapidly passed to make provision for up to three days of voting in future elections at all levels, and to continue to mandate voting in 'adjacent areas' to polling stations. Ostensibly these should widen ballot access, but they will inevitably place more demands on election officials, as well as making the process of electoral observation and the prevention of fraud harder to guarantee. In regional elections held in September 2020, the three-day voting arrangement was already in place, and looks set to remain for the future.

Alongside the positives for the Kremlin, there are also some caveats. The strong headline rate of support masks the fact that turnout was low in many regions, and opponents of the reforms stayed at home in significant numbers, potentially exaggerating the extent of real underlying support. The large number of votes from the more 'managed' republics has in recent years made up for the general lack of engagement in the majority of regions, and in this respect the referendum result continued the trend of recent elections. If the current regime is indeed hoping to continue successfully until the mid-203os, it must be careful to lay claim to genuine legitimacy and public engagement in order to remain sustainable. In the long-term, it is a potentially risky strategy to rely on high turnouts in a narrow range of regions whose results are questionable. The fall in trust in the electoral system should give pause for thought, after two recent federal elections that were generally thought to have been better administered than usual.

\section{Acknowledgement}

This work was carried out with the aid of a grant from ICLD (Sweden). 